\title{
Bee flora diversity in different vegetation communities of Gesha- Sayilem forest in Kaffa Zone, south-western Ethiopia
}

\author{
Tura Bareke* and Admassu Addi \\ Oromia Agricultural Research Institute, Holeta Bee Research Center, Ethiopia \\ *Corresponding Author: trbareke@gmail.com
}

\begin{abstract}
Tropical Afromontane forest has the potential for honey production. The main objective of the study was to identify major bee floras and its diversity in different vegetation communities of Gesha-Sayilem forest. Bee flora data were collected systematically from 90 plots with subplots for shrubs and herbaceous species. In addition, pollen traps having $16 \%$ pollen trapping efficiency were fitted at the entrance of beehives for pollen load collection. Shannon-Wiener diversity index; species richness and Shannon's evenness were employed to determine diversity of bee flora. The result showed that 93 bee plant species belongings to 43 families were identified of which Asteraceae the most abundant family was followed by Lamiaceae, Fabaceae, Acanthaceae and Rubiaceae. The analysis of bee forage diversity using Shannon-Wiener diversity index $(\mathrm{H})$ found in 5 different plant communities showed that plant communities one, two, and three have the highest bee flora diversity 3.2, 3.2, and 3.5, respectively. The dominant bee plants in community one were (Ilex mitis and Syzygium guineens), community two (Pouteria adolfi-friederici and Schefflera abyssinica), Community three (Millettia ferruginea and Sapium ellipticum), community four (Hagenia abyssinica and Dombeya torrida), community five (Schefflera-volkensi and Maesa lanceolata). Sorensen similarity coefficient showed that communities 1, 2, 3 , and 5 are more similar to each other while community four is less similar. On the other hand, the beta diversity for communities 1 , 2,3 , and 5 were $0.25,0.27,0.39$, and 0.28 respectively while community four has a higher beta diversity index (0.71) indicating low similarity with the rest of the plant communities. In conclusion community 1, 2 and 3 has a high diversity of bee flora and therefore, integration of these communities with beekeeping is recommended.
\end{abstract}

Keywords: Plant, Honeybee, Pollen, Dominant, Nectar, Honey.

\section{INTRODUCTION}

Ethiopia is one of the world's most plant species-rich countries (Senbeta et al., 2014; Kelbessa \& Demissew, 2014; Kassa et al., 2016). As a result, it is an origin of diversity and endemism for several plant species (Husen et al., 2012; Assefa et al., 2014; Tadesse et al., 2017; Yahya et al., 2019). Ethiopia has about 6000 species of higher plants including 647 (10.74\%) endemic taxa (Kelbessa \& Demissew, 2014; Gebrehiwot \& Hundera, 2014). The natural forests of Ethiopia have ecological and economical values (FAO, 2016; Arts \& de Koning, 2017; Macqueen et al., 2018; Guta \& Telake, 2019). However, it is highly under pressure (Senbeta et al., 2014; Tadesse et al., 2017; Shiferaw et al., 2018). In Ethiopia, the main causes of deforestation are for agricultural expansion, charcoal production, settlements, for fuelwood and construction material (Tura et al., 2017; Yirga et al., 2019). The south-west montane forests are mainly depleted for coffee plantation (Wood et al., 2019).

Beekeeping is one of the most important agricultural activities in many parts of Ethiopia. The diversified agro-climatic conditions of the country create conducive environmental conditions for the growth of thousands of flowering plants of which most are honeybee plants (Bareke \& Addi, 2018; Bareke \& Addi, 2019a). Annually 54,000 metric tons of honeys are produced in Ethiopia, 24\% of the Africa production, representing a value of about 620 million Birr (CSA 2015). The Moist Afromontane Forests of South-west Ethiopia have the potential for beekeeping that would serve as a major source of household income (Bareke \& Addi, 2019a). In the Kaffa zone, there is an intact natural forest, a dense honeybee population and huge water resources. Honey production is an important source of income for smallholder farmers in the area. As a result, the large volume of honey is produced annually.

In most parts of the south-west forest of Ethiopia, honey production is the second important agricultural activity next to Ensete (Ensete ventricosum (Welw.) Cheesman.) and average of 20-30 beehives are owned by households. Although the yields vary with the rainfall in the area, one hive can produce about $10-15 \mathrm{~kg} / \mathrm{hive}$ from traditional beehives and 30 $52 \mathrm{~kg} /$ hive from improved beehives (Getachew et al., 2012). The honey is used both as a source of food and medicine for local communities, as well as a source of revenue.

Beekeepers in the Gesha-Sayilem forest have a better understanding of the value of the forest for honey production. For instance, the traditional beekeepers in the area have long-established traditional forest management practices, which locally called "KOBO". KOBO is a block of forest land bounded and demarcated by big trees and or physical features 
like the river and small streams and exclusively used for the purpose of traditional beekeeping (Addi, 2018). From the forest resource management perspective, forest beekeeping is the most important activity, that connects the farmers' economies with the preservation of the forest trees and it also contributes in the pollination of wild and cultivated crops in the area. In Kaffa zone, wild coffee forest is the major crop pollinated by honeybees and contributes for maintenances of Coffee genetic resources. Samnegård et al. (2014) made a survey of coffee pollinators under different shade-tree structures found that the native honeybee (Apis mellifera) is the dominant visitor of coffee flowers and hence contributing in the pollination of coffee plants. Gesha-Sayilem forest has five plant communities that are found in different altitudinal gradient (Addi et al., 2020). These are 1. Ilex mitis-Syzygium guineense community type. It occurs between altitudinal ranges of 1834-2408 $\mathrm{m}$ above sea level and found on the east facing slope. 2. Pouteria adolfifriederici-Schefflera abyssinica community type. It occurs between 1734-2803 m above sea level and found on moderate slope facing towards south. 3. Millettia ferruginea-Sapium ellipticum community. It is found between 1722$2316 \mathrm{~m}$ a.s.l. and on gentle slope. 4. Arundinaria alpine community. It occurs between 2350-2506 m at lower slope (17.2\%) facing to the south-west direction. 5. Schefflera volkensi-Maesa lanceolate community type. This community type is found between 1968 and $2800 \mathrm{~m}$ facing towards the north east (Addi, 2018). Despite the potentiality of the forest for honey production, there is lack of information on bee floral diversity and abundance. Therefore, the present study aimed to identify the major bee forage plants and diversity of bee flora in different plant communities of the Gesha and Sayilem districts of South-west Ethiopia.

\section{MATERIALS AND METHODS}

\section{Study area}

The study was carried out in Gesha-Sayilem forest. This forest is found in the two districts of Gesha and Sayilem in Kaffa Zone of Southern Nations Nationalities Peoples Regional State (Fig. 1). The southern part of Gesha district is bordered by Bita district in the west by the Sheka Zone, in the North by Ilubbabor Zone of Oromia Region and in the east by Gewata district.

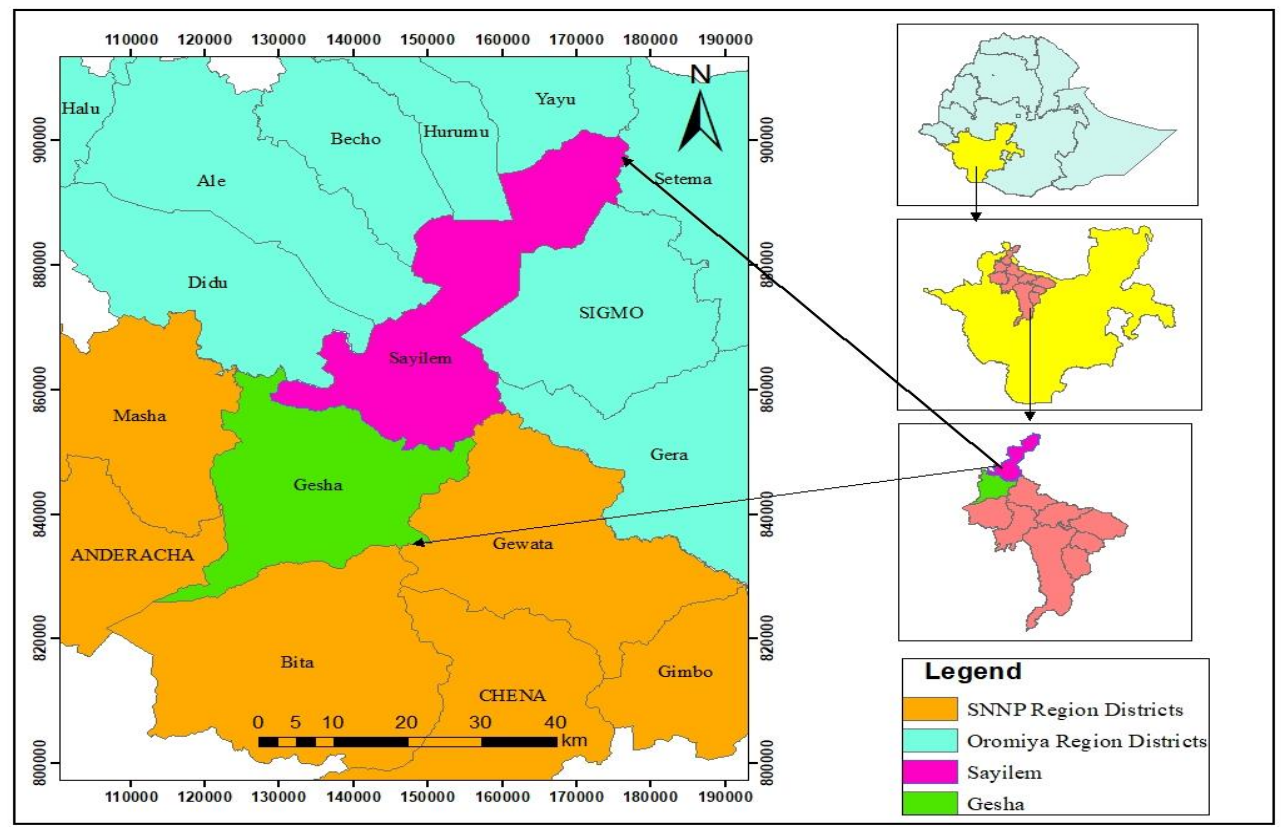

Figure 1. Map of the study area. [Source: Addi et al., 2020]

\section{Bee flora data collection}

Systematic sampling design were employed on the basis of altitudinal gradients, because of the rugged and undulating nature of the topography of the area and its inaccessibility to collect of representative bee flora data. The quadrats were laid down with altitudinal difference of $200 \mathrm{~m}$ and all the plots were laid down 50 meter away from the road in order to avoid boundary effects. The sizes of quadrats were $625 \mathrm{~m}^{2}, 25 \mathrm{~m}^{2}$ and $1 \mathrm{~m}^{2}$ for trees, shrubs and lianas, and herbs, respectively, in a nested plot design (Kent \& Coker, 1992; Kent, 2011). A total of 90 large quadrats were laid down, 18 quadrats in each of the plant communities of the forest (Addi et al., 2020).

Plants visited by honeybees were observed in various sites of the study forest. During the observations, the types of food source offered by plants and the behavior of the honeybees while collecting nectar and pollen were noted (Bareke \& Addi 2019a). Moreover, the flowering periods of plants visited by honeybees were also recorded throughout the year. Geographical Positioning System (GPS), plant press (flat wooden frames) including newspaper, ventilator cardboard, 
blotter with the size of $42 \mathrm{~cm} \times 26 \mathrm{~cm}$, secateurs (pruning scissors) and ethanol $(70 \%)$ are materials used to collect and dry plant specimen for identification.

\section{Pollen collection}

This is used to identify plants that highly preferred by honeybees in addition to field observation. For this, a total of 10 modern beehives were placed in all plant communities, 2 in each plant community of the study area. Pollen traps having $16 \%$ pollen trapping efficiency were fitted at the entrance of beehives. Pollen loads were collected for one year (September 2017 to September 2018). A total of 300 samples of bee pollen loads were collected and used for the identification of the botanical origin of the pollen. The pollen loads were sorted by color and then, slide prepared for the identification. Photographs of different views of the pollen grains were taken using Zeiss light microscope magnification power of 40X linked with computer software (Fig. 2).

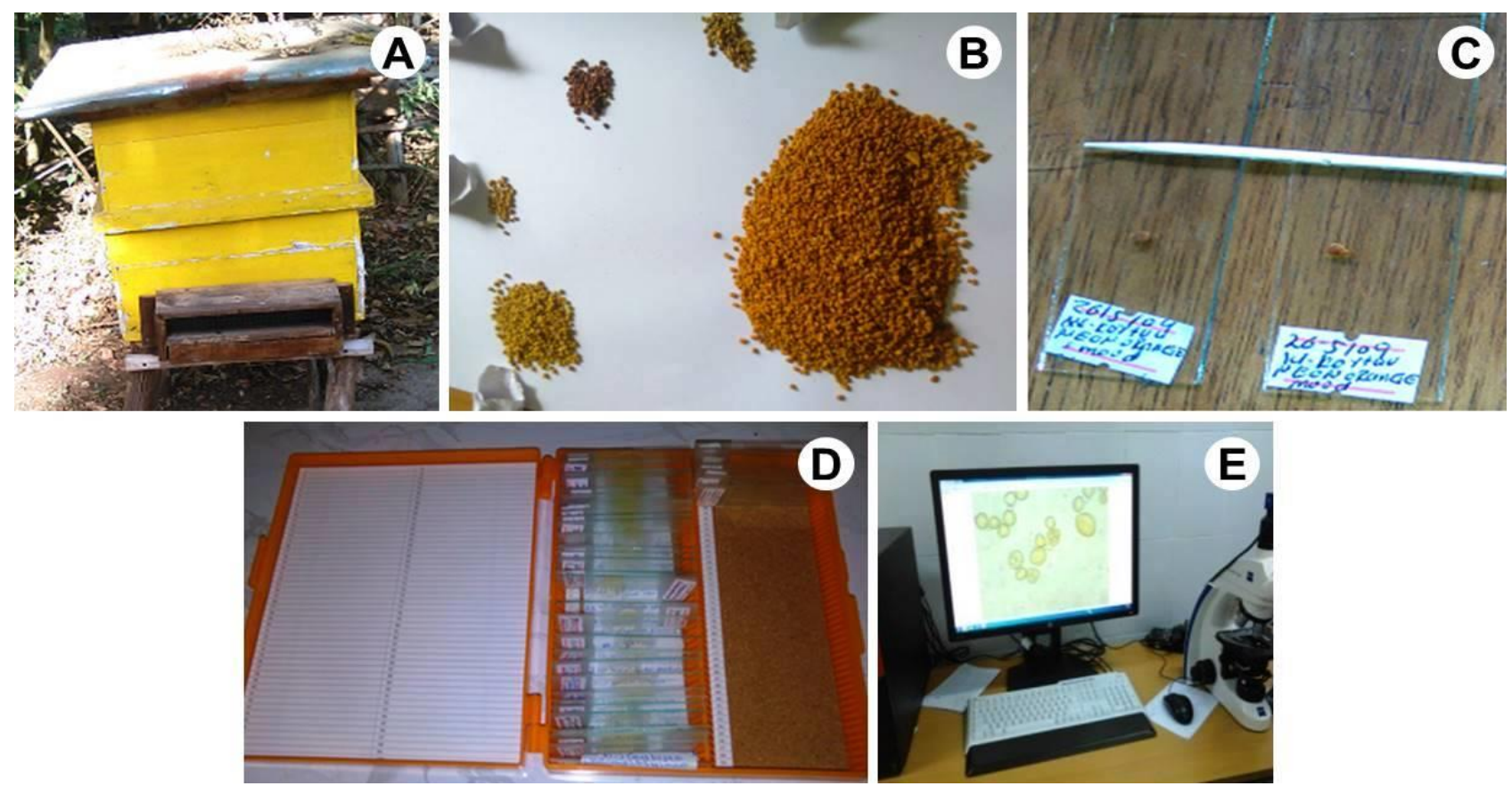

Figure 2. A, Modern bee hive fitted with pollen trap; B, Sorted pollen into homogenous color; $\mathbf{C}$, Slide preparation; $\mathbf{D}$, Stored slide in slide box; E, Pollen under identification using Zeiss light microscope.

\section{Richness and diversity of bee forage plants}

Species diversity of plants was quantified in different plant communities using Shannon-Wiener diversity index; species richness and Shannon's evenness. Shannon-Wiener diversity index is the most popular measure of species diversity that cannot be affected by sample size.

The Shannon-Wiener Index is used to calculate the diversity of bee plants (Ramirez-Arriaga et al., 2011).

$$
\text { Shannon Index }\left(\mathbf{H}^{\prime}\right)=-\sum_{i=1}^{s}(\mathrm{Pi} \times \ln \mathrm{Pi})
$$

Where, $\mathrm{H}^{\prime}=$ Shannon diversity index; $s=$ Number of species; $i=1$; Pi = Proportion of individuals or the abundance of the $i^{\text {th }}$ species; $\ln =\log$ base $n$.

$$
\text { Evenness }(\mathbf{J})=\frac{\mathrm{H}^{\prime}}{\mathrm{H}^{\prime} \max }=\frac{\mathrm{H}^{\prime}}{\text { ins }}
$$

Where, $H^{\prime}=$ Shannon-Wiener diversity index; H'max= $\ln \mathrm{s}$ where $\mathrm{s}$ is the number of species; $\ln =\log$ base ${ }_{\mathrm{n}}$; Value of evenness is ranged from 0 to 1 (Kent \& Coker, 1992).

\section{Floristic similarity analysis}

Plant communities can differ in species composition; richness and relative abundance of species (evenness). To estimate the similarity between the communities a number of different similarity indices were applied. Similarity coefficients measure the degree to which the species compositions of quadrats or samples are alike (Kent \& Coker, 1992). Sorensen similarity (Ss) coefficient is a widely used index that gives more weight to the common species of the samples (Kent \& Coker, 1992). The similarity coefficient value ranges from 0 (complete dissimilarity) to 1 (total similarity). In this comparison, $\beta$-diversity between community types was also computed using the formula $\beta$-diversity, Where $\mathrm{a}$ is the number shared species between two sites, and $\mathrm{b}$ and $\mathrm{c}$ are the numbers of species unique to each site. High species turnover would indicate high $\beta$-diversity or a low level of similarity. Thus, the floristic similarity of the 
community types in the present study was assessed using the Sorenson's coefficient of similarity using statistical program in R software (R Core Development Team 2011).

$$
\text { The formula for Sorensen similarity }(\boldsymbol{S} \boldsymbol{s})=\frac{2 a}{2 a+b+c}
$$

Where, $a=$ Number of species common to both community types; $b=$ Number of species in one of the community to be compared; $c=$ Species present in the other site.

\section{RESULTS AND DISCUSSION}

\section{Bee forage composition and diversity}

Based on bee plant inventory, observation and pollen load collection a total of 93 plant species belong to 43 families were identified (Table 1). The growth forms of bee forage utilized by honeybees comprise $36.6 \%$ herb, $25.8 \%$ shrubs, $23.6 \%$ trees and 14\% climbers (Fig. 3). Similar study conducted in Zerat Afromontane Forest in North Shewa Zone of Amhara Regional State of Ethiopia (Abebe \& Temam, 2016) and in Gurage Mountains reported that herbs account for a large proportion of plants encountered in the forests (Tamru, 2014). Asteraceae family has the highest species comprising 20 species (21.5\%) and followed by Lamiaceae and Fabaceae 5 (5.4\%) each in the area (Fig. 4). Study conducted in Gera forest also indicates that Asteraceae is the most frequent family, represented by the highest species composition in the area (Bareke \& Addi, 2019a). However, a study conducted by Yohannes et al. (2015) in the Gera forest indicates that the Fabaceae family is dominant while Asteraceae is the second dominant. This study was not done in view of beekeeping and it was about general floristic composition of the forest. All species of Fabaceae family are not bee forage plants. Due to this, it is not a dominant honeybee plant family in different forest area. But, in view of beekeeping Asteraceae family is the dominant bee forage family in many forest areas; this could be attributed to the potential of its species for honey production. Figure 5 shows the photographed images of some bee forage plants inventoried and identified in in Gesha-Sayilem forest.

Table 1. Checklist of plant species identified from the study area.

\begin{tabular}{|c|c|c|c|c|}
\hline Plant species & Family & Habit & $\begin{array}{l}\text { Flowering } \\
\text { period }\end{array}$ & $\begin{array}{l}\text { Food } \\
\text { source }\end{array}$ \\
\hline Acanthopale ethio-germanica Ensermu & Acanthaceae & Herb & Sep-Nov & $\mathrm{N} \& \mathrm{P}$ \\
\hline Acanthus eminens C.B. Clarke & Acanthaceae & Herb & Sep-Nov & $\mathrm{N} \& \mathrm{P}$ \\
\hline Achyranthes aspera L. & Amaranthaceae & Herb & Aug-Dec & $\mathrm{P}$ \\
\hline Achyrospermum schimperi (Hochst. ex Briq.) Perkins & Lamiaceae & Herb & Sep-Oct & $\mathrm{P}$ \\
\hline Acmella caulirhiza Del. & Asteraceae & Herb & Sep-Nov & $\mathrm{N} \& \mathrm{P}$ \\
\hline Aframomum corrorima (Braun) Jansen & Zingiberaceae & Herb & Jun-Jul & $\mathrm{N} \& \mathrm{P}$ \\
\hline Ageratum conyzoides $\mathrm{L}$. & Asteraceae & Herb & Sep-Dec & $\mathrm{N} \& \mathrm{P}$ \\
\hline Albizia gummifera (J.F.Gmel.) C.A.Sm & Fabaceae & Tree & Jan-Apr & $\mathrm{N} \& \mathrm{P}$ \\
\hline Allophyllus abyssinicus (Hochst.) Radlk. & Sapindaceae & Tree & Sep-Oct & $\mathrm{N} \& \mathrm{P}$ \\
\hline Andropogon abyssinicus Fresen & Poaceae & Herb & Sep-Oct & $\mathrm{P}$ \\
\hline Apodytes dimidiata E. Mey. ex Arn. & Icaccinaceae & Tree & Sep-Nov & $\mathrm{N} \& \mathrm{P}$ \\
\hline Aspilia mossambicensis (Oliv.) Wild & Asteraceae & Herb & Sep-Nov & $\mathrm{N} \& \mathrm{P}$ \\
\hline Basella alba $\mathrm{L}$ & Basellaceae & Climber & Sep-Oct & $\mathrm{N} \& \mathrm{P}$ \\
\hline Bersama abyssinica Fresen. & Melianthaceae & Tree & Sep-Nov & $\mathrm{N} \& \mathrm{P}$ \\
\hline Bidens prestinaria (Sch. Bip.) Cufod. & Asteraceae & Herb & Sep-Nov & $\mathrm{N} \& \mathrm{P}$ \\
\hline Bothriocline schimperi Olivo \& Hiern ex Benth. & Asteraceae & Herb & Sep-Dec & $\mathrm{N} \& \mathrm{P}$ \\
\hline Brassica carinata $\mathrm{A} . \mathrm{Br}$ & Brassicaceae & Herb & Sep-Oct & $\mathrm{N} \& \mathrm{P}$ \\
\hline Brucea antidysenterica J. F. Mill. & Simaroubaceae & Shrub & Sep-Oct & $\mathrm{N} \& \mathrm{P}$ \\
\hline Buddleja polystachya Fresen. & Loganiaceae & Shrub & Sep-Oct & $N \& P$ \\
\hline Celtis africana Burm. f. & Ulmaceae & Shrub & Sep-Nov & $\mathrm{N} \& \mathrm{P}$ \\
\hline Circium schimperi (Yatke) C. Jeffrey cufod & Asteraceae & Herb & Sep-Oct & $\mathrm{P}$ \\
\hline Clausena anisata (Wild.) Benth. & Rutaceae & Shrub & Sep-Dec & $\mathrm{N} \& \mathrm{P}$ \\
\hline Clematis simensis Fresen. & Ranunculaceae & Climber & Sep-Dec & $\mathrm{N} \& \mathrm{P}$ \\
\hline Coffea arabica $\mathrm{L}$. & Rubiaceae & Shrub & Feb-Mar & $\mathrm{N} \& \mathrm{P}$ \\
\hline Croton macrostachyus Del. & Euphorbiaceae & Tree & Apr-June & $\mathrm{N} \& \mathrm{P}$ \\
\hline Datura innoxia Mill. & Solanaceae & Shrub & Sep-Mar & $\mathrm{N} \& \mathrm{P}$ \\
\hline Dombeya torrida (J.F. Gmel.) P.Bamps & Sterculiaceae & Tree & Sep-Nov & $\mathrm{N} \& \mathrm{P}$ \\
\hline Ehretia cymosa Thonn. & Boraginaceae & Shrub & Sep-Dec & $\mathrm{N} \& \mathrm{P}$ \\
\hline Eucalyptus camaldulensis Dehnh & Myrtaceae & Tree & Mar-Apr & $\mathrm{N} \& \mathrm{P}$ \\
\hline Eucalyptus globulus Labill & Myrtaceae & Tree & Mar-Apr & $\mathrm{N} \& \mathrm{P}$ \\
\hline Ekebergia capensis Sparrm. & Meliaceae & Tree & Jan-Feb & $\mathrm{N} \& \mathrm{P}$ \\
\hline Galiniera saxifraga (Hochst.) Bridson & Rubiaceae & Shrub & Sep-Dec & $\mathrm{N} \& \mathrm{P}$ \\
\hline Galinsoga quadriradiata Ruiz \& Pavon & Asteraceae & Herb & Sep-Oct & $\mathrm{N} \& \mathrm{P}$ \\
\hline
\end{tabular}




\begin{tabular}{|c|c|c|c|c|}
\hline Glycine wightii (Wight \& Am.) Verdc. & Fabaceae & Climber & Sep-Dec & $\mathrm{N} \& \mathrm{P}$ \\
\hline Gouania longispicata Engl. & Rhamnaceae & Climber & Sep-Dec & $\mathrm{N} \& \mathrm{P}$ \\
\hline Guizotia scabra (Vis.) Chiov. & Asteraceae & Herb & Sep-Nov & $\mathrm{N} \& \mathrm{P}$ \\
\hline Hagenia abyssinica (Bruce) J.F. Gmel. & Rosaceae & Tree & Oct-Dec & $\mathrm{N} \& \mathrm{P}$ \\
\hline Helichrysum formosissimum Sch. Bip. ex A. Rich & Asteraceae & Herb & Sep-Oct & $\mathrm{N} \& \mathrm{P}$ \\
\hline Hibiscus berberidifolius A. Rich. & Malvaceae & Shrub & Sep-Oct & $\mathrm{N} \& \mathrm{P}$ \\
\hline Hibiscus ludwigii Eckl. \& Zeyh. & Malvaceae & Shrub & Sep-Oct & $\mathrm{N} \& \mathrm{P}$ \\
\hline Hypericum revolutum Vahl & Hypericaceae & Shrub & Sep-Oct & $\mathrm{N} \& \mathrm{P}$ \\
\hline Hypoestes triflora (Forssk.) Roem \& Schult & Acanthaceae & Herb & Sep-Oct & $\mathrm{N} \& \mathrm{P}$ \\
\hline Ilex mitis (L.) Radlk. & Aquifoliaceae & Tree & Sep-Oct & $\mathrm{N} \& \mathrm{P}$ \\
\hline Impatiens ethiopica Grey-Wilson & Balsaminaceae & Herb & Aug-Oct & $\mathrm{N} \& \mathrm{P}$ \\
\hline Ipomea purpurea (L.) Roth. & Convolvulaceae & Climber & Sep-Oct & $\mathrm{N}$ \\
\hline Ipomea indica (Burm.f) Merrill & Convolvulaceae & Climber & Sep-Oct & $\mathrm{N} \& \mathrm{P}$ \\
\hline Isoglossa somalensis Lindau & Acanthaceae & Herb & Sep-Dec & $\mathrm{N} \& \mathrm{P}$ \\
\hline Jasminum abyssinicum Hochst. ex DC & Oleaceae & Climber & Dec-Jan & $\mathrm{N} \& \mathrm{P}$ \\
\hline Justicia schimperiana (Hochst. ex Nees) T. Anders. & Oleaceae & Climber & Sep-Dec & $\mathrm{N} \& \mathrm{P}$ \\
\hline Laggera crispata Vahl Hepper \& Wood & Asteraceae & Herb & Sep-Oct & $\mathrm{P}$ \\
\hline Maesa lanceolata Forssk. & Myrsinaceae & Shrub & Sep-Oct & $\mathrm{N} \& \mathrm{P}$ \\
\hline Malva verticillata $\mathrm{L}$. & Malvaceae & Herb & Sep-Nov & $\mathrm{N} \& \mathrm{P}$ \\
\hline Maytenus undata (Thunb.) Blaelock & Cleastraceae & Shrub & Sep-Nov & $\mathrm{P}$ \\
\hline Mikaniopsis clematoides (S'ch. Bip. ex A. Rich.) Milne-Redh. & Asteraceae & Climber & Sep-Nov & $\mathrm{N} \& \mathrm{P}$ \\
\hline Millettia ferruginea (Hochst.) Bak. & Fabaceae & Tree & Dec-Jan & $\mathrm{N} \& \mathrm{P}$ \\
\hline Nuxia congesta $\mathrm{R}$. Br. ex Fresen. & Loganiaceae & Shrub & Sep-Nov & $\mathrm{N} \& \mathrm{P}$ \\
\hline Ocimum sp. & Lamiaceae & Herb & Sep-Nov & $\mathrm{N} \& \mathrm{P}$ \\
\hline Olea welwitschii (Knobl.) Gilg \& Schellenb. & Oleaceae & Tree & May-Jun & $\mathrm{N} \& \mathrm{P}$ \\
\hline Pentas schimperiana (A. Rich.) Vatke & Rubiaceae & Shrub & Sep-Oct & $\mathrm{N} \& \mathrm{P}$ \\
\hline Periploca linearifolia Quart. Dill \& A. Rich. & Asclepiadaceae & Climber & Sep-Dec & $\mathrm{N} \& \mathrm{P}$ \\
\hline Phoenix reclinata Jacq. & Arecaceae & Tree & Sep-Dec & $\mathrm{N} \& \mathrm{P}$ \\
\hline Phytolacca dodecandra L 'Herit. & Phytolaccaceae & Climber & Sep-Dec & $\mathrm{N} \& \mathrm{P}$ \\
\hline Piper capense $\mathrm{L}$. & Piperaceae & Herb & Apr-June & $\mathrm{P}$ \\
\hline Plantago lanceolata $\mathrm{L}$. & Plantaginaceae & Herb & Oct-Dec & $\mathrm{P}$ \\
\hline Polyscias fulva (Hiern) Harms & Araliaceae & Tree & Oct-Dec & $\mathrm{N} \& \mathrm{P}$ \\
\hline Pouteria adolfi-friederici (Engl.) Baehni & Sapotaceae & Tree & May-Jun & $\mathrm{N}$ \\
\hline Premna schimperi Engl. & Verbenaceae & Shrub & Sep-Oct & $\mathrm{N} \& \mathrm{P}$ \\
\hline Prunus africana (Hook. f.) Kalkm. & Roseaceae & Tree & Sep-Oct & $\mathrm{N} \& \mathrm{P}$ \\
\hline Psycnostachys eminii Gurke & Lamiaceae & Herb & Sep-Dec & $\mathrm{N} \& \mathrm{P}$ \\
\hline Ranunculus multifidus Forssk. & Ranunculaceae & Herb & Sep-Dec & $\mathrm{N} \& \mathrm{P}$ \\
\hline Rhamnus prinoides L'Herit. & Rhamnaceae & Herb & Sep-Dec & $\mathrm{N} \& \mathrm{P}$ \\
\hline Rothmannia urcelliformis (Hiern) Robyns & Rubiaceae & Shrub & Sep-Dec & $\mathrm{N}$ \\
\hline Rubus steudneri Schweinf. & Roseaceae & Climber & Sep-Dec & $\mathrm{N} \& \mathrm{P}$ \\
\hline Salix subserrata Willd. & Salicaceae & Shrub & Sep-Dec & $\mathrm{N} \& \mathrm{P}$ \\
\hline Salvia nilotica Juss. ex Jacq. & Lamiaceae & Herb & Sep-Oct & $N \& P$ \\
\hline Sapium ellipticum (Hochst.) Pax & Euphorbiaceae & Tree & Oct-Dec & $\mathrm{N} \& \mathrm{P}$ \\
\hline Satureja paradoxa (Vatke) Engl. & Lamiaceae & Herb & Sep-Oct & $\mathrm{N} \& \mathrm{P}$ \\
\hline Schefflera abyssinica (Hochst ex A. Rich) Harms & Araliaceae & Tree & Ma-Apr & $\mathrm{N} \& \mathrm{P}$ \\
\hline Schefflera volkensi (Engl.) Harms & Araliaceae & Tree & Ma-Apr & $\mathrm{N} \& \mathrm{P}$ \\
\hline Solanecio gigas (Vatke) C. Jeffrey & Asteraceae & Herb & Sep-Dec & $\mathrm{N} \& \mathrm{P}$ \\
\hline Solanecio mannii (Hook. f.) C. Jeffrey & Asteraceae & Shrub & Sep-Dec & $\mathrm{P}$ \\
\hline Sphaeranthus suaveolens (Forssk.) DC. & Asteraceae & Herb & Sep-Dec & $\mathrm{N} \& \mathrm{P}$ \\
\hline Syzygium guineense (Willd.) DC. & Myrtaceae & Tree & Feb-Mar & $\mathrm{N} \& \mathrm{P}$ \\
\hline Trifolium polystachyum Fresen. & Fabaceae & Herb & Sep-Oct & $\mathrm{N} \& \mathrm{P}$ \\
\hline Vepris dainellii Pic.Serm & Rutaceae & Tree & Dec-Jan & $\mathrm{P}$ \\
\hline Vernonia amygdalina Del & Asteraceae & Shrub & Dec-Jan & $\mathrm{N} \& \mathrm{P}$ \\
\hline Vernonia auriculifera Hiern & Asteraceae & Shrub & Dec-Jan & $\mathrm{N} \& \mathrm{P}$ \\
\hline Vernonia hochstetteri Sch. Bip. ex Walp. & Asteraceae & Shrub & Dec-Jan & $\mathrm{N} \& \mathrm{P}$ \\
\hline Vernonia ituriensis Muschl. & Asteraceae & Shrub & Dec-Jan & $\mathrm{N} \& \mathrm{P}$ \\
\hline Vernonia leopoldi (Sch. Bip. ex Walp.) Votke & Asteraceae & Shrub & Dec-Jan & $N \& P$ \\
\hline Vernonia wollastonii S'. Moore & Asteraceae & Climber & Dec-Jan & $\mathrm{N} \& \mathrm{P}$ \\
\hline Vicia faba $\mathrm{L}$. & Fabaceae & Herb & Sep & $\mathrm{N} \& \mathrm{P}$ \\
\hline Zea mays L. & Poaceae & Herb & Aug-Sep & $\mathrm{P}$ \\
\hline
\end{tabular}

Note: P- Pollen, N- Nectar, N \& P- Nectar and Pollen. 
From the identified 93 bee plants $85 \%$ of them provide both nectar and pollen sources while $11.8 \%$ were pollen sources and 3.2\% nectar sources (Table 1). This indicated that pollen source plants are numerous than nectar sources. Nectar is used for honey production while pollen is for colony multiplication. Therefore, nectar source plants were fewer as compared to pollen sources. Not all bee plants are equally important to honeybees as well as for honey production. The sources of most of the world's honey are only about $16 \%$ of the flowering plants (Crane, 1990). This indicates that for every geographical region there are very few important honey source plants.

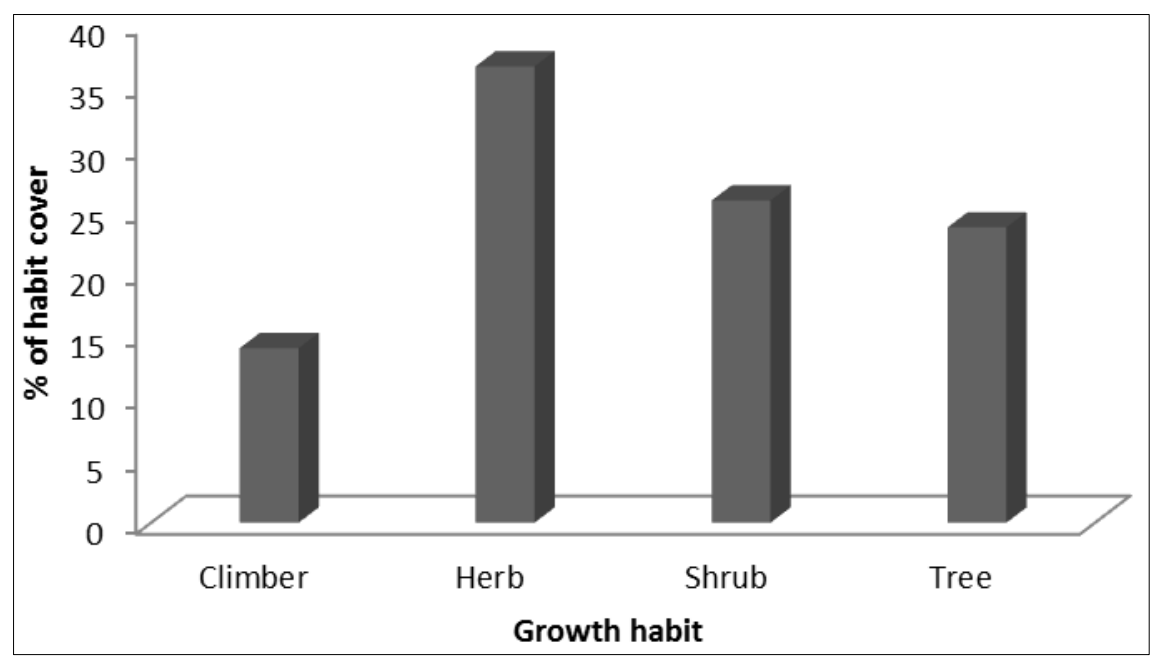

Figure 3. The growth habit of bee forages in the study area.

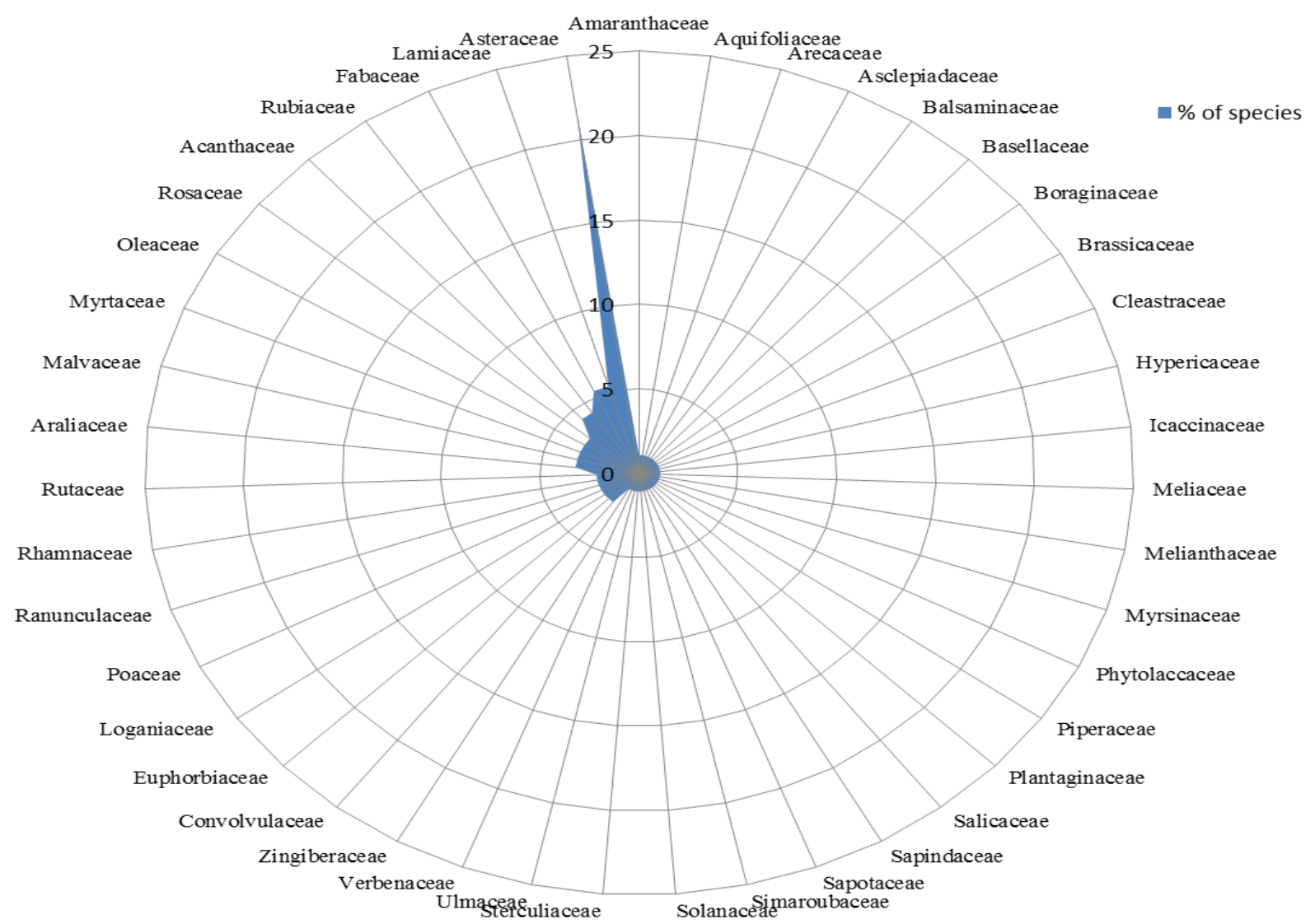

Figure 4. Percentages of plant species from different families identified in the forest.

The south-western parts of the country have relatively high percentage of forest cover that makes the area highly suitable for beekeeping. According to the secondary data collected from the District office of the Ministry of Agriculture, the forest cover varies from $22 \%$ to $70 \%$ of the total land area which makes the area is an ideal for beekeeping. In this study, relatively smaller bee forage species compositions were recorded as compared to the floristic richness of the forest in the area. This is attributed due to a floral preference of honeybees, nectar and pollen production of the plants and climatic factors of the area. Asteraceae has the highest species richness comprising followed by 
Lamiaceae and Acanthaceae. A similar study conducted by Addi \& Bareke (2019) and Bareke \& Addi (2019a) reported that Asteraceae is the most frequent families represented by the highest number of bee forage species. The dominance of the Asteraceae family could be attributed to the potential of its species for honey production (Bareke \& Addi 2019a). However, many authors have mentioned that Fabaceae the dominant family (Gurmessa et al., 2013; Kuma \& Shibru, 2015 ). This is not in view of beekeeping rather general floristic composition because there are many Fabaceae species that are not bee forage. On the other hand, the dominant family is varied from place to place.
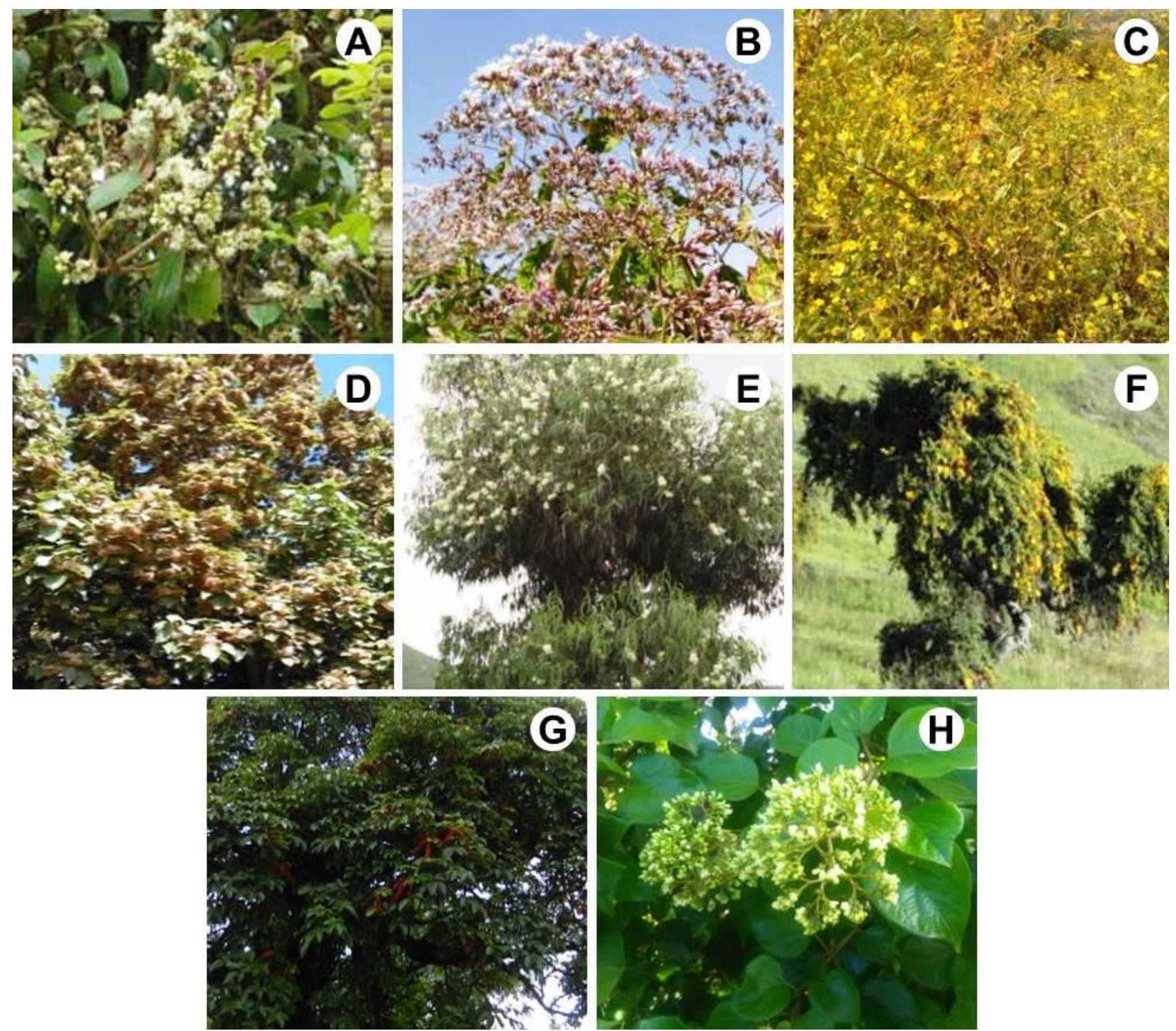

Figure 5. Some bee forage plant species in vegetation communities of Gesha-Sayilem forest in Kaffa Zone, south-western Ethiopia: A, Ilex mitis (L.) Radlk.; B, Vernonia auriculifera Hiern; C, Guizotia scabra (Vis.) Chiov.; D, Dombeya torrida (J.F. Gmel.) P.Bamps; E, Eucalyptus globulus Labill; F, Hypericum revolutum Vahl; G, Schefflera abyssinica (Hochst ex A. Rich) Harms; H, Premna schimperi Engl.

\section{Species diversity}

The analysis of bee forage diversity using Shannon-Wiener diversity index found in different plant communities was indicated in table 2. Accordingly, the plant community one, two and three has the highest bee plant diversity $3.2,3.2$ and 3.5, respectively. Relatively lower species diversity and species richness were recorded for community four and five (2.1 and 2.3) respectively. Community one, two and three have highest species richness (55, 55 and 45) respectively and lower number of species recorded for the communities four and five (14 and 11 respectively). The dominant bee forages for honey production in community one were (Ilex mitis (L.) Radlk, and Syzygium guineens (Willd.) DC.), community two (Pouteria adolfi-friederici (Engl.) Baehni, and Schefflera abyssinica (Hochst ex A. Rich) Harms), Community three (Millettia ferruginea (Hochst.) Bak., and Sapium ellipticum (Hochst.) Pax), community four (Hagenia abyssinica (Bruce) J.F. Gmel. and Dombeya torrida (J.F. Gmel.) P.Bamps.), community five (Schefflera volkensi (Engl.) Harms and Maesa lanceolata Forssk.) plant community. Study conducted by Bareke \& Addi (2018) in Guji zone indicates that Syzygium guineense (Willd.) DC., Ilex mitis (L.) Radlk and Schefflera abyssinica (Hochst ex A. 
Rich) Harms are the major bee forage plants that can provide monofloral honey. The high diversity of bee flora resource was found in from community one to three. According to study conducted by Addi et al. (2020), in community 1 the dominant tree species were Allophyllus abyssinicus (Hochst.) Radlk, Croton macrostachyus Del. and Apodytes dimidiata E. Mey. ex Arn. while the shrubs include Galiniera saxifraga (Hochst.) Bridson, Brucea antidysenterica J. F. Mill and Clausena anisata (Wild.) Benth. The herb layer comprises Hypoestes triflora (Forssk.) Roem \& Schult and Achyranthes aspera L. Community 2 is dominated in the upper canopy by Schefflera abyssinica (Hochst ex A. Rich) Harms, Albizia gummifera (J.F.Gmel.) C.A.Sm, Ekebergia capensis Sparrm., and Ilex mitis (L.) Radlk. trees and they are major bee forage plants in the area. Vernonia auriculifera Hiern the dominant bee forage shrub in the community 2. The herb layer is dominated by Acanthus eminens C.B. Clarke and Piper capense L. The dominant trees in the community 3 are Millettia ferruginea (Hochst.) Bak., Olea welwitschii (Knobl.) Gilg \& Schellenb, Albizia gummifera (J.F.Gmel.) C.A.Sm., Polyscias fulva (Hiern) Harms and Sapium ellipticum (Hochst.) Pax while shrubs include Vepris dainellii Pic.Serm and Coffea arabica L. as well as Aframomum corrorima (Braun) Jansen bee forage herb in the area. The climbers/lianas include Clematis simensis Fresen, and Jasminum abyssinicum Hochst. ex DC. Many authors have been reported that Schefflera abyssinica (Hochst ex A. Rich) Harms, Ilex mites (L.) Radlk, Vernonia auriculifera Hiern, Croton macrostachyus Del, Coffea arabica L., Syzygium guineense (Willd.) DC., Clematis simensis Fresen, Hypoestes triflora (Forssk.) Roem \& Schult and Albizia gummifera (J.F.Gmel.) C.A.Sm. are the major bee forage plants in different parts of Ethiopia (Bareke \& Addi, 2018; Bareke \& Addi 2019b; Bareke et al., 2020).

Table 2. The bee forages diversity in Gesha-Sayilem forest in different plant communities.

\begin{tabular}{lrrr}
\hline Communities & Richness & Shannon & Evenness \\
\hline Community one & 55 & 3.2 & 0.82 \\
Community two & 45 & 3.2 & 0.86 \\
Community three & 55 & 3.53 & 0.88 \\
Community four & 14 & 2.32 & 0.89 \\
Community five & 11 & 2.1 & 0.89 \\
\hline
\end{tabular}

\section{Similarity among the plant communities}

Pair's wise comparison of the Sorensen similarity coefficient gave a higher value between the plant communities comprising bee forages table 2 . Accordingly, the communities 1,2,3 and 5 are more similar to each other as shown in table 3. Community four is with a similarity ratio of 0.29 can be considered to be less similar from other communities. On the other hand, the beta diversity for communities $1,2,3$ and 5 were $0.25,0.27,0.39$ and 0.28 respectively while community four has a higher beta diversity index (0.71) indicating low similarity with rest of the plant communities. The analysis of species composition for each community indicated that community one, two and three had the highest species composition $(92,96,88)$ respectively followed by community four and five (30 and 70) respectively.

Table 3. Pairwise comparison of similarity index between the community groups.

\begin{tabular}{lrrrrr}
\hline Plant community & Community 1 & Community 2 & Community3 & Community4 & Community5 \\
\hline 1 & 1 & $0.74(0.26)$ & $0.68(0.32)$ & $0.33(0.67)$ & $0.51(0.49)$ \\
2 & $0.75(0.25)$ & 1 & $65(0.35)$ & $0.26(0.74)$ & $0.45(0.55)$ \\
3 & $0.73(0.27)$ & $0.66(0.34)$ & 1 & $0.24(0.76)$ & $0.46(0.54)$ \\
4 & $0.29(0.71)$ & $0.28 .3(0.72)$ & $0.25(0.75)$ & 1 & $0.38(0.62)$ \\
5 & $0.39(.0 .41)$ & $0.40(0.60)$ & $0.42(0.58)$ & $0.22(0.88)$ & 1 \\
\hline
\end{tabular}

Note: Numbers in bracts indicate $\beta$-diversity.

\section{Pollen load analysis}

The highest proportion of pollen loads were collected from Guizotia scabra (Vis.) Chiov, (20.5\%), Bidens prestinaria (Sch. Bip.) Cufod (13.5\%), Croton macrostachyus Del. (12.7\%), Datura innoxia Mill. (11.1\%), Syzygium guineense (Willd.) DC (7.2\%), Eucalyptus globulus Labill (6.5\%), Plantago lanceolata L. (5.3\%), Vernonia amygdalina Del. (4.5\%) and Maesa lanceolata Forssk. (3.7\%) and the rest of the plants contributing for little proportion (Fig. 6). About $42.3 \%$ of pollen was collected from September-November, $32.2 \%$ from December to January, $18.9 \%$ during March to May and $6.2 \%$ of pollen during June to August. Among the flowering plant species, Eucalyptus camaldulensis Dehnh, Datura innoxia Mill., Apodytes dimidata E. Mey. ex Arn., Olea welwitschii (Knobl.) Gilg \& Schellenb had the longest flowering period and provided continuous nectar and pollen supply for foraging honeybees.

Out of the total identified bee forages only thirty-six plant species were identified as the source of the pollen. The highest proportion of pollen comes from only a few plants mainly from forest trees, weeds and hedge plants. These included Guizotia scarba (Vis.) Chiov., Vernonia auriculifera Hiern, Datura innoxia Mill. (introduced and planted a live fence), Trifolium polystachya Fresen, Zea mays L., Ilex mitis (L.) Radlk., Apodytes dimidiata E. Mey. ex Arn. and Croton macrostachyus Dell. The rest of plant species may contribute little amount of pollen or provide a high amount of 
nectar. The amount and diversity of pollen were influenced by season but not by landscape diversity (Danner et al., 2017). The diversity of collected pollen is important for honeybee health (Alaux et al., 2010). It is an essential for the growth, development and reproduction of honey bee colonies (Di Pasquale et al., 2013). A study conducted by Piroux et al. (2014) also reported that the foraging distances as well as the amount and diversity of the pollen diet are affected by the types of plants found in landscape. Less diverse landscapes with lower bee forage resource availability lower input and diversity of the pollen.

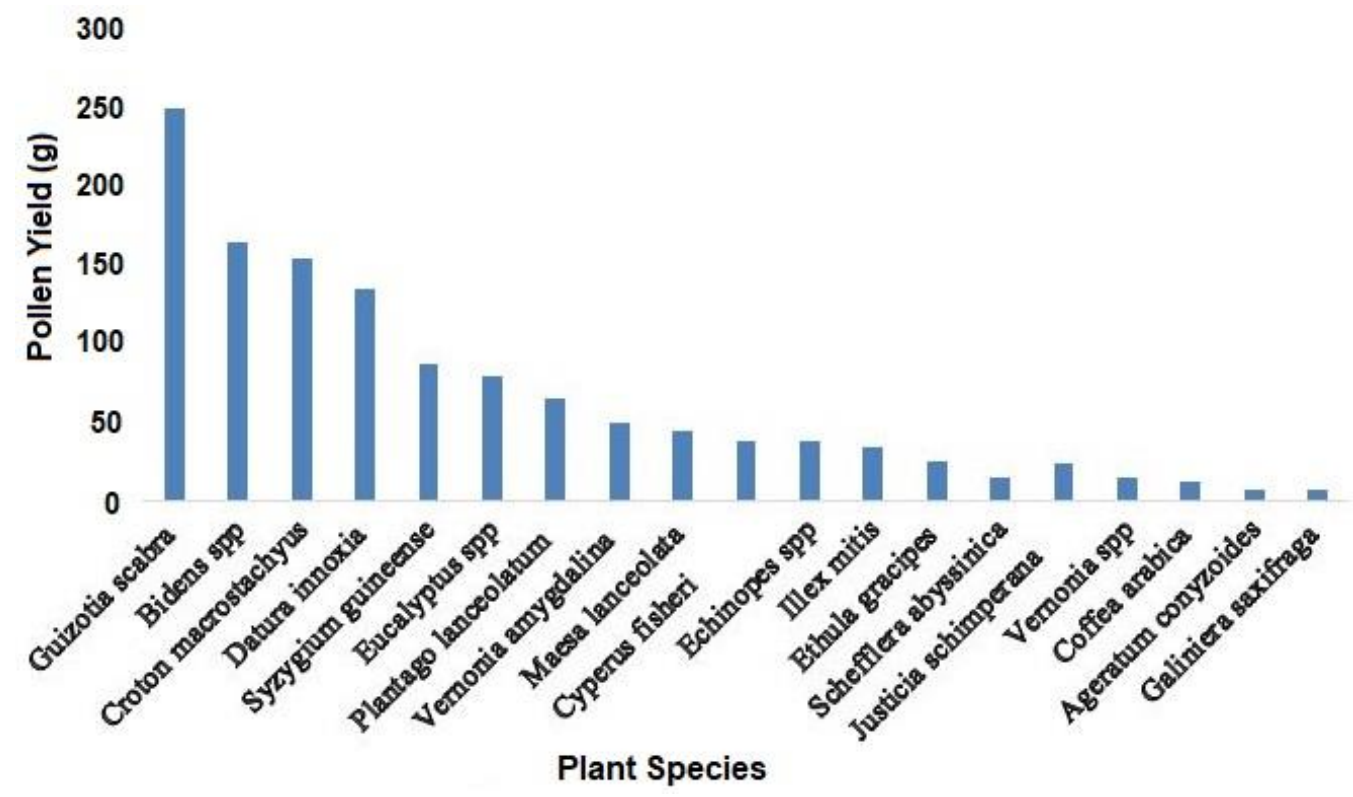

Figure 6. Pollen yields of bee forages.

The highest pollen load is collected from September to January and April to May and lowest during dry and rainy months (February and July). The highest pollen yield was obtained during October and November due to the fact that the majority of plant species flower after the long rainy season (June-August) and the short rainy season (March to April) reaching peak in October and April. A similar study conducted by Bareke \& Addi (2019a) in Gera forest indicated that the majority of pollen source plants are flowered in September to October. On the other hand, the lowest pollen yield was recorded June to August which is the main rainy season in the area. The rain affects the flight conditions of honeybees which in turn reduces their capacity for pollen collection. Similar study has been reported by Lamessa et al. (2008) during the rainy season, low temperatures possibly inhibit the growth and flowering of the plant species whereas the higher temperature during the dry period result in water deficiency in plants resulting in low nectar secretion and pollen collection.

\section{CONCLUSION}

In conclusion, this forest has the high diversity of bee flora resource. The beekeepers should follow the flowering calendar of the plant to harvest honey, sequentially.

\section{ACKNOWLEDGEMENTS}

We acknowledge the Holeta Bee Research Center and Oromia Agricultural Research Institute for providing required facilities and logistics.

\section{REFERENCES}

Abebe D. \& Temam T.D. (2016). Floristic Composition and Structure of Zerat Forest, Central Ethiopia. American Scientific Research Journal for Engineering, Technology, and Sciences, 18(1): 326-342.

Addi A. \& Bareke T. (2019). Review : Floral resources diversity of honeybees in important types of vegetation of Ethiopia. Asian Journal of Forestry, 3(2): 64-68.

Addi A. (2018). The Ecology, Carbon Stock, Bee Forage diversity In A Moist Afromontane Forest Of Gesha And Sayilem Districts In Kaffa Zone, South West Ethiopia, (M.Sc. Thesis). Addis Ababa University, Ethiopia.

Addi A., Soromessa T. \& Bareke T. (2020). Plant diversity and community analysis of Gesha and Sayilem Forest in Kaffa Zone, southwestern Ethiopia. Biodiversitas, 21(7): 2878-2888.

Alaux C., Ducloz F., Crauser D. \& Le Conte Y. (2010). Diet effects on honeybee immunocompetence. Biology Letters, 6(4): 562565 .

Arts B. \& de Koning J. (2017). Community forest management: an assessment and explanation of its performance through QCA. World Development, 96: 315-325. 
Assefa A., Demissew S. \& Woldu Z. (2014). Floristic composition, structure and regeneration status of Masha forest, south-west Ethiopia. African Journal of Ecology, 52(2): 151-162.

Bareke T. \& Addi A. (2018). Honeybee Flora Resources of Guji Zone, Ethiopia. Journal of Biology, Agriculture and Healthcare, 8(21): 1-9.

Bareke T. \& Addi A. (2019a). Bee flora resources and honey production calendar of Gera Forest in Ethiopia. Asian Journal of Forestry, 3(2): 69-74.

Bareke T. \& Addi A. (2019b). Pollen analysis of honey from Borana zone of Southern Ethiopia. Journal of Apicultural Science, 63(2): 233-242.

Bareke T., Kumsa T., Roba K. \& Addi A. (2020). Nectar Secretion Dynamics and Honey Production Potential of Croton macrostachyus L., Euphorbiaceae. Bee World, 97(4): 123-127.

Crane E. (1990). Bees and beekeeping: Science, practice and world resources. Heinnmann Newness.

CSA (Central Stastics Agency) (2015). Federal Democratic Republic of Ethiopia Report On: Livestock and Livestock Characteristics (Private Peasant Holdings). Addis Ababa.

Danner N., Keller A., HaÈrtel S. \& Steffan-Dewenter I. (2017). Honey bee foraging ecology: Season but not landscape diversity shapes the amount and diversity of collected pollen. PLoS ONE, 12(8): e0183716. [DOI: 10.1371/journal.pone.0183716]

Di Pasquale G., Salignon M., Le Conte Y., Belzunces L.P., Decourtye A. \& Kretzschmar A. (2013). Influence of Pollen Nutrition on Honey Bee Health: Do Pollen Quality and Diversity Matter? PLoS ONE, 8(8): e72016. [DOI: 10.1371/journal.pone.0072016]

FAO (2016). Forty Years of Community-Based Forestry. A Review of Its Extent and Effectiveness. FAO, Rome FAO Forestry Paper 176.

Gebrehiwot K. \& Hundera K. (2014). Species composition, Plant Community structure and Natural regeneration status of Belete Moist Evergreen Montane Forest, Oromia Regional state, Southwestern Ethiopia. Momona Ethiopian Journal of Science, 6(1): 97-101.

Getachew A., Shenkute A.G., Getachew Y., Assefa D. \& Adgaba N. (2012). Honey production systems (Apis mellifera L.) in Kaffa, Sheka and Bench-Maji zones of Ethiopia. Journal of Agricultural Extension and Rural Development, 4(19): 528-541.

Gurmessa F., Soromessa T. \& Kelbessa E. (2013). Floristic Composition and Community Analysis of Komto Afromontane Moist Forest, East Wollega Zone, West Ethiopia. Science, Technology and Arts Research Journal, 2(2): 58-69.

Guta D.D. \& Telake B.B. (2019). Assessments of woody vegetation in Addis Ababa city, Ethiopia. Plants and Environment, 1(1): $17-30$.

Husen A., Mishra V.K., Semwal K. \& Kumar D. (2012). Biodiversity Status in Ethiopia and Challenges. In: Bharati K.P., Chauhan A. \& Kumar P. (Eds.) Environmental Pollution and Biodiversity, Vol. 1. Discovery Publishing House Pvt Ltd., New Delhi, India, pp. 31-79.

Kassa Z., Asfaw Z. \& Demissew S. (2016). Plant diversity and community analysis of the vegetation around Tulu Korma project centre, Ethiopia. Tropical Plant Research, 3(2): 292-319.

Kelbessa E. \& Demissew S. (2014). Diversity of vascular plant Taxa of the Flora of Ethiopia and Eritrea. Ethiopian Journal of Biological Sciences, 13: 37-45.

Kent M. \& Coker R. (1992). Vegetation description and analysis: A practical approach. CRC Press, Inc., London.

Kent M. (2011). Vegetation description and data analysis: a practical approach. John Wiley \& Sons.

Kuma M. \& Shibru S. (2015). Floristic Composition, Vegetation Structure, and Regeneration Status of Woody Plant Species of Oda Forest of Humbo Carbon Project, Wolaita, Ethiopia. Journal of Botany, 2015: 963816. [DOI: 10.1155/2015/963816]

Lamessa D., Achalu N. \& Addi A. (2008). Honey pollen and bee pollen Load Analysis for Vegetation Characterization and Implications for Honey Plant Growing and Conservation: The Case of Walmera Woreda, Central Ethiopia. Ethiopian Journal of Natural Resources, 32: 249-265.

Macqueen D., Bolin A., Greijman M., Grouwels S. \& Humphries S. (2018). Innovations towards prosperity emerging in locally controlled forest business models and prospects for scaling up. World Development, 125: 104382. [DOI: 10.1016/j.worlddev.2018.08.004]

Piroux M., Lambert O., Puyo S., Farrera I., Thorin C. \& L'Hostis M. (2014). Correlating the Pollens Gathered by Apis Mellifera with the Landscape Features in Western France. Applied Ecology and Environmental Research, 12(2): 423-439.

$\mathrm{R}$ Core Development Team (2011). R: A language and environment for statistical computing. R Foundation for Statistical Computing, 360 Vienna, Austria. [ISBN 3-900051-07-0]

Ramirez-Arriaga E., Navarro-Calvo L.A. \& Diaz-Carbajal E. (2011). Botanical characterization of Mexican honeys from a subtropical region (Oaxaca) based on pollen analysis. Grana, 50(1): 40-54.

Samnegård U., Hambäck P., Nemomissa S. \& Hylander K. (2014). Dominance of the semi-wild honeybee as coffee pollinator across a gradient of shade-tree structure in Ethiopia. Journal of Tropical Ecology, 30: 401-408.

Senbeta F., Christine S., Woldemariam T., Hans Juergen B. \& Manfred D. (2014). Plant Diversity, Vegetation Structure and Relationship between Plant Communities and Environmental Variables in the Afromontane Forests of Ethiopia. Ethiopian Journal of Science, 37(2):113-130.

Shiferaw W., Lemenih M. \& Gole T.W.M. (2018). Analysis of plant species diversity and forest structure in Arero dry Afromontane forest of Borena zone, South Ethiopia. Tropical Plant Research, 5(2): 129-140.

Tadesse Z., Kelbessa E. \& Bekele T. (2017). Floristic composition and plant community analysis of vegetation in Ilu Gelan district, West Shewa Zone of Oromia region, Central Ethiopia. Tropical Plant Research, 4(2): 335-350. 
Tamru D. (2014). The Forest Patches of Gurage Mountains: Floristic Composition, Ecology and Anthropogenic Influences. Addis Ababa University, Ethiopia, (Ph.D. dissertation).

Tura T., Soromessa T., Leta S. \& Argaw M. (2017). Plant Community Composition and Structure of Asabot Dry Afromontane Forest, West Harare Zone, Ethiopia. Journal of Biodiversity \& Endangered Species, 5(4): 1-12.

Wood A., Tolera M., Snell M., O'Hara P. \& Hailu A. (2019). Community forest management (CFM) in south-west Ethiopia: Maintaining forests, biodiversity and carbon stocks to support wild coffee conservation. Global Environmental Change, 59: 1-11.

Yahya N., Gebre B. \& Tesfaye G. (2019). Species diversity, population structure and regeneration status of woody species on Yerer Mountain Forest, Central Highlands of Ethiopia. Tropical Plant Research, 6(2): 206-213.

Yirga F., Marie M., Kassa S. \& Haile M. (2019). Impact of altitude and anthropogenic disturbance on plant species composition, diversity, and structure at the Wof-Washa highlands of Ethiopia. Heliyon, 5: 1-13.

Yohannes M., Tamrat B. \& Ensermu K. (2015). Floristic Composition, Species Diversity and Vegetation Structure Of Gera Moist Montane Forest, Jimma Zone Of Oromia National Regional State, Southwest Ethiopia. Ethiopian Journal of Biological Sciences, 14(1): 45-68. 